\title{
Infeksi Saluran Kemih Sebagai Penyebab Kolestasis Intrahepatik
}

\author{
Hanifah Oswari, Harijadi, Julfina Bisanto, Purnamawati SP
}

\begin{abstract}
Diagnosis banding etiologi kolestasis intrahepatik $(\mathrm{KIH})$ pada bayi sangat beragam, salah satu di antaranya adalah infeksi dan yang tersering adalah infeksi saluran kemih (ISK). Infeksi saluran kemih pada KIH akan mempunyai prognosis baik bila dapat didiagnosis dan diobati. Pengamatan sehari-hari di Departemen Ilmu Kesehatan Anak FKUI/RS Dr. Cipto Mangunkusumo didapatkan kesan bahwa ISK pada KIH cukup sering ditemukan. Penelitian ini bertujuan untuk mengetahui prevalensi ISK pada bayi dengan KIH dan mengetahui karakteristik pasien tersebut. Subyek adalah bayi dengan kolestasis intrahepatik yang berusia kurang dari 1 tahun yang datang berobat di Divisi Gastrohepatologi di Departemen Ilmu Kesehatan Anak FKUI/RSCM pada periode Januari sampai dengan Desember 2003. Diagnosis ISK ditegakkan bila ditemukan bakteriuria lebih dari $100.000 \mathrm{cfu} / \mathrm{mL}$. Hasil penelitian ini mendapatkan prevalens ISK pada bayi dengan KIH sebesar 24 dari 34 subyek, dengan dominasi lelaki (3:1). Bakteri penyebab tersering adalah bakteri Gram negatif ditemukan sebanyak 21 dari 24 subyek. Pada lima belas dari 24 orang di antaranya ditemukan $E$. coli. Tidak ada gejala klinis yang spesifik pada kolestasis dengan ISK. Gejala demam ditemukan pada 3 dari 24 subyek . Leukosituria ditemukan pada 1 dari 24 subyek dengan ISK. Oleh sebab itu dianjurkan untuk melakukan pemeriksaan biakan urin untuk mendeteksi ISK.
\end{abstract}

Kata kunci: kolestasis intrahepatik, infeksi saluran kemih, E.coli

$C$ dar bilirubin direk lebih dari $1,5 \mathrm{mg} / \mathrm{dL}$ atau lebih dari $15 \%$ konsentrasi bilirubin total pada bayi merupakan keadaan abnormal dan disebut dengan kolestasis, memerlukan pemeriksaan lebih lanjut. ${ }^{1}$ Kolestasis dapat terjadi karena defek pembentukan empedu pada tingkat hepatosit (kolestasis hepatoselular) atau karena gangguan sekresi dan aliran empedu pada tingkat duktulus atau duktus biliaris (kolestasis duktular). ${ }^{2}$

\footnotetext{
Alamat korespondensi:

Dr. Hanifah Oswari, Sp.A

Departemen Ilmu Kesehatan Anak FKUI/RSCM

Jl. Salemba 6 Jakarta.

Telp/fax 021-3915712. Email: hanifah@idai.or.id
}

Hasil penelitian ini telah disampaikan pada Pertemuan Ilmiah Tahunan Ilmu Kesehatan Anak II IDAI, Batam, 12-14 Juli 2004
Secara klinis, kolestasis dapat terjadi pada kelainan intrahepatik maupun ekstrahepatik. Dalam praktek sehari-hari terdapat deretan panjang diagnosis banding etiologi kolestasis, terutama kolestasis intrahepatik. Usaha untuk menemukan penyebab kolestasis memerlukan biaya yang cukup besar, namun tidak semua penyebab dapat diobati. Dari deretan panjang etiologi kolestasis tersebut infeksi merupakan salah satu penyebabnya, baik intrahepatik maupun ekstrahepatik. Infeksi bakteri pada neonatal yang berhubungan dengan ikterus telah lama dilaporkan dan umumnya berhubungan dengan infeksi saluran kemih (ISK) ${ }^{3,4}$ Umumnya infeksi ini terjadi antara usia 2 minggu sampai 8 minggu. ${ }^{5}$

Pada pengamatan sehari-hari di Departemen Ilmu Kesehatan Anak FKUI/RS Cipto Mangunkusumo, ISK sering ditemukan pada bayi dengan kolestasis intrahepatik. Kolestasis intrahepatik dengan ISK merupakan penyakit yang dapat diterapi, relatif mudah 
didiagnosis, dan mempunyai prognosis baik bila diterapi dengan adekuat. Tujuan penelitian ini adalah untuk mengetahui prevalens ISK pada bayi dengan $\mathrm{KIH}$ dan karakteristik pasien di Bagian Ilmu Kesehatan Anak FKUI/RSCM, Jakarta.

\section{Metode penelitian}

Penelitian ini adalah penelitian deskriptif retrospektif. Subyek penelitian adalah bayi dengan kolestasis intrahepatik yang berusia kurang dari 1 tahun di Departemen Ilmu Kesehatan Anak FKUI/RSCM pada periode Januari sampai dengan Desember 2003. Data diambil dari catatan medik Departemen IKA FKUI/ RSCM. Pasien yang dirawat di bangsal perawatan perinatologi tidak dimasukkan dalam penelitian ini.

Selama periode penelitian biakan urin secara rutin dilakukan pada bayi dengan kolestasis. Biakan urin dilakukan dengan menggunakan kantung urin steril, setelah membersihkan daerah genitalia. Diagnosis ISK ditegakkan bila ditemukan bakteriuria bermakna, yaitu lebih dari $100.000 \mathrm{cfu} / \mathrm{mL}$ urin. Leukosituria diartikan dengan leukosit dalam urin $>5 / \mathrm{LPB}$. Kolestasis ditegakkan bila kadar bilirubin direk $>1,5 \mathrm{mg} / \mathrm{dl}$ atau merupakan lebih dari 15\% komponen bilirubin total. Kolestasis intrahepatik adalah kolestasis yang telah disingkirkan terhadap kemungkinan kolestasis ekstrahepatik dengan melihat tinja 3 porsi, pemeriksaan laboratorium, USG hati dan saluran empedu 2 fase dan biopsi hati (bila diperlukan)

Karakteristik subyek pada penelitian ini berupa jenis kelamin, berat lahir, usia keluhan pertama kali kuning, usia datang berobat pertama kali ke RSCM, ada tidaknya demam, dan ada tidaknya hepatomegali.
Data laboratorium meliputi kadar albumin, globulin, bilirubin total, bilirubin direk, bilirubin indirek, persentase bilirubin direk dibandingkan bilirubin total, gamma glutamil transferase (GGT), alanine amino transferase (ALT), aspartate aminotransferase (AST), waktu protrombin (PT), kolesterol total, leukosit urin, ureum, dan kreatinin darah. Karakteristik subyek dan gejala klinis dibedakan antara KIH dengan ISK dan tanpa ISK. Jenis bakteri penyebab ISK juga dicatat. Pengobatan kolestasis dianggap berhasil bila kadar bilirubin direk, indirek, dan total menjadi normal dalam pengamatan lanjutan.

\section{Hasil penelitian}

Pada periode Januari sampai dengan Desember 2003 di Departemen Ilmu Kesehatan Anak FKUI/RSCM tercatat 99 menderita dengan kolestasis, 68 di antaranya dengan KIH. Dari 68 orang bayi tersebut, biakan urin dilakukan pada 34 bayi, dan didapatkan bakteriuria bermakna pada 24 bayi. Pada pemantauan selanjutnya, pada 11 dari 24 bayi kadar bilirubin menjadi normal. Karakteristik sampel penelitian tertera pada Tabel 1. Data gambaran laboratorium subyek dapat dilihat selengkapnya pada Tabel 2 .

Sebagian besar kuman penyebab ISK pada penelitian ini adalah E. coli (15/24), Staphylococcus epidermidis (3/24), Enterobacter aerogenes dan Proteus mirabilis masing-masing 2, dan Klebsiela sp serta Providencia stuartii masing-masing 1.

Sebelas dari 24 pasien yang diberi antibiotik dan asam ursodeoksikolat, vitamin larut dalam lemak, sembuh dan kadar bilirubin menjadi normal. tiga belas orang lainnya sebagian mengalami perbaikan atau tidak datang kembali berobat.

Tabel 1. Karakteristik sampel penelitian

\begin{tabular}{lcc}
\hline Karakteristik & $\begin{array}{c}\text { Biakan positif } \\
\mathrm{n}=24\end{array}$ & $\begin{array}{c}\text { Biakan negatif } \\
\mathrm{n}=10\end{array}$ \\
\hline Jenis kelamin (laki-laki:perempuan) & $18: 6$ & $3: 7$ \\
Berat lahir*(gram) $^{*}$ & 3075 & 2400 \\
Usia keluhan pertama*(hari) & $(1600-4000)$ & $(1400-3100)$ \\
Usia datang berobat*(minggu) & $7(0-200)$ & $22(1-80)$ \\
Demam & $9(5-32)$ & $8,5(5-14)$ \\
Hepatomegali & 3 & 0 \\
\hline
\end{tabular}

* median 
Sari Pediatri, Vol. 6, No. 4, Maret 2005

Tabel 2. Gambaran laboratorium

\begin{tabular}{|c|c|c|}
\hline Laboratorium & $\begin{array}{c}\text { Biakan urin }(+) \\
n=24\end{array}$ & $\begin{array}{c}\text { Biakan urin }(-) \\
\mathrm{n}=10\end{array}$ \\
\hline Albumin $(\mathrm{g} / \mathrm{dL})^{* *}$ & $3,32 \pm 0,6$ & $3,97 \pm 0,6$ \\
\hline Globulin $(\mathrm{g} / \mathrm{dL}) *$ & $2,23(1-4,78)$ & $2,2(1,4-5,02)$ \\
\hline Bilirubin total $(\mathrm{mg} / \mathrm{dL})^{*}$ & $8,9(5,3-21,2)$ & $7,7(2,8-19,7)$ \\
\hline Bilirubin direk $(\mathrm{mg} / \mathrm{dL})^{*}$ & $6,5(2,2-16,6)$ & $5,5(2-14,4)$ \\
\hline Bilirubin indirek $(\mathrm{mg} / \mathrm{dL}) *$ & $1,8(0,6-6,5)$ & $1,8(0,1-5,4)$ \\
\hline Bilirubin direk / total ${ }^{*}$ & $0,8(0,3-0,9)$ & $0,75(0,6-0,9)$ \\
\hline Gamma GT $(\mathrm{u} / \mathrm{L})^{*}$ & $186(14-486)$ & $168(69-378)$ \\
\hline $\operatorname{AST}(\mathrm{u} / \mathrm{L}) *$ & $122(41-352)$ & $188(19-469)$ \\
\hline $\operatorname{ALT}(\mathrm{u} / \mathrm{L})^{*}$ & $82,5(27-431)$ & $189(19-429)$ \\
\hline PT (detik)* & $15(10-100)$ & $14,6(12-21)$ \\
\hline Kolesterol total $(\mathrm{mg} / \mathrm{dL}) *$ & $187(105-292)$ & $193(115-237)$ \\
\hline Leukosit urin > 5/LPB* & 1 & 0 \\
\hline Ureum darah $(\mathrm{mg} / \mathrm{dL})^{*}$ & $17(13-49)$ & $15(13-21)$ \\
\hline Kreatinin darah $(\mathrm{mg} / \mathrm{dL}) *$ & $0,65(0,2-0,97)$ & $0,5(0,1-0,65)$ \\
\hline
\end{tabular}

* Median ; ${ }^{* *}$ Mean

\section{Diskusi}

Menurut Seeler, ikterus merupakan salah satu tanda infeksi saluran kemih pada bayi kecil. Pada tahun 1977, Seeler melaporkan 24 bayi yang diberi susu botol yang dipulangkan dari perawatan bayi karena terlihat normal, ternyata kembali dengan gejala ikterus. Bayi tersebut kemudian diketahui menderita ISK. ${ }^{3}$ Chavalithdhamrong dkk melaporkan 69 neonatus asimptomatik dengan ikterus yang tidak dapat dijelaskan penyebabnya, ternyata pada pemeriksaan selanjutnya terbukti karena ISK oleh Gram negatif pada 2 bayi. ${ }^{6}$ Rooney dkk melaporkan 22 bayi ikterus dengan infeksi bakteri, 9 di antaranya adalah ISK. ${ }^{7}$ Garcia dkk melaporkan bayi dengan ikterus, tanpa gejala demam berumur 8 minggu 7,5\% di antaranya karena ISK, dan 2 dari 12 merupakan kolestasis. ${ }^{8}$ Penelitian ini mendapatkan prevalens ISK pada $\mathrm{KIH}$ sebesar 24 dari 34 pasien. dari kepustakaan yang ada, belum pernah dilaporkan insidens kolestasis karena ISK di Indonesia.

Pada minggu pertama kehidupan, gejala ikterus umumnya disebabkan oleh peningkatan bilirubin indirek; keadaan ini terjadi pada hampir $50 \%$ bayi. Pada hari ke 3-5 umumnya kadar bilirubin mencapai puncaknya dan membaik setelah usia tujuh hari. Bila pada usia 2 minggu bayi masih terlihat ikterus, maka pemeriksaan bilirubin direk dan indirek perlu dilakukan karena kemungkinan merupakan kolestasis.
Pada penelitian ini, usia keluhan ikterus pertama kali untuk kelompok pasien dengan $\mathrm{KIH}$ dengan biakan urin positif, rata-rata (median) 7 hari lebih cepat dibandingkan dengan pasien dengan biakan negatif (22 hari). Pasien KIH baik dengan atau tanpa biakan urin positif umumnya datang sangat terlambat, sekitar minggu ke 8-9. Terdapat jeda yang cukup panjang antara gejala ikterus sampai pasien dibawa ke RSCM. Pada umumnya orang tua pasien (dan juga sebagian tenaga medis) tidak menyadari bahwa gejala kuning setelah usia 2-3 minggu kemungkinan merupakan kolestasis. Pada umumnya orangtua pasien masih menjemur bayinya yang sebenarnya tidak bermanfaat untuk kolestasis.

Infeksi saluran kemih bergejala lebih sering pada perempuan. Heldrich melaporkan, $68 \%$ bayi dengan ISK berusia kurang dari 2 tahun adalah perempuan, ${ }^{10}$ Pada penelitian ini ternyata terjadi hal yang sebaliknya, pada pasien KIH dengan ISK terlihat dominasi lelaki (3:1). Hasil penelitian ini ternyata sesuai dengan penelitian ISK pada bayi dengan gejala dini ikterus yang juga melaporkan dominasi lelaki (9:3). ${ }^{8}$ Seeler juga melaporkan dominasi lelaki pada infeksi bakteri yang berhubungan dengan ikterus (18:3). ${ }^{3}$ Masih belum jelas mengapa terjadi demikian.

Bayi dengan hepatitis neonatal idiopatik yang termasuk kolestasis intrahepatik umumnya lahir prematur atau dengan berat lahir rendah, berbeda dengan atresia bilier (kolestasis ekstrahepatik) yang 
predominan perempuan dan dengan berat lahir normal. Pada penelitian ini berat lahir pasien $\mathrm{KIH}$ dengan biakan positif terlihat normal (median 3075 gram), berbeda dengan KIH dengan biakan negatif yang terlihat lebih kecil. Garcia dkk melaporkan pada kelompok pasien dengan biakan positif rerata berat lahir adalah 3360 gram. ${ }^{8} \mathrm{Ng}$ dan Rawstron melaporkan hal yang sama, seluruh (6) pasien yang dilaporkan (ISK dengan gejala ikterus) lahir dengan berat lebih dari 3000 gram. $^{4}$

Infeksi bakteri, seperti pada umumnya ISK dengan gejala ikterus jarang berhubungan dengan gejala demam atau gejala yang berhubungan dengan berkemih. ${ }^{3,5} \mathrm{Ng}$ dan Rawstron melaporkan hanya 2 dari 6 pasien ISK dengan gejala ikterus yang disertai demam. Pada penelitian ini, pasien KIH dengan biakan urin positif umumnya tidak memberikan gejala demam. Hanya 3 dari 24 pasien dengan riwayat atau gejala demam. Gejala hepatomegali ditemukan pada 22 dari 24 pasien KIH dengan biakan urin positif dan tidak berbeda dengan kelompok KIH dengan biakan urin negatif (9 dari 10 pasien).

Gambaran laboratorium pasien KIH dengan biakan positif maupun negatif masih menunjukkan fungsi sintesis hati yang baik, terbukti dari hasil albumin dan waktu protrombin yang masih normal. Hal ini menunjukkan bahwa walaupun pasien datang terlambat pada sekitar minggu ke-8 dan 9, fungsi hati masih relatif baik. Tidak terlihat perbedaan kadar globulin dan kolesterol pada subyek dengan biakan positif dan negatif.

Pasien KIH dengan biakan positif maupun negatif menunjukkan hasil bilirubin anak yang hampir sama yaitu sekitar 5-6 mg/dl. Kadar bilirubin indirek juga kurang lebih sama sekitar 1,8 $\mathrm{mg} / \mathrm{dl}$. Pada penelitian ini kadar bilirubin total pada KIH didapatkan dengan median 8,9 mg/dl (5,3-21,2 $\mathrm{mg} / \mathrm{dl}$ ) dan $80 \%$ komponen bilirubin total adalah bilirubin direk. Hal ini sesuai dengan laporan sebelumnya bahwa bilirubin serum berkisar antara 5 dan $10 \mathrm{mg} / \mathrm{dl}$ dengan karakteristik $75-80 \%$ dari bilirubin serum adalah bilirubin direk, walaupun kadar 30-50 mg/dl juga dilaporkan. ${ }^{11,12}$ Kadar gamma GT pada subyek penelitian ini tidak terlalu tinggi dengan median $186 \mathrm{mg} / \mathrm{dl}$, kurang lebih sama dengan KIH dengan biakan urin negatif. Peningkatan moderat gamma GT dan serum transaminase (AST dan ALT) yang normal atau sedikit meninggi telah pula dilaporkan. ${ }^{11,12}$ Pada penelitian ini nilai transaminase pasien $\mathrm{KIH}$ dengan biakan positif dan biakan negatif terlihat tidak berbeda, kurang lebih 3-5 kali batas atas normal.

Leukosituria secara tradisi digunakan sebagai petanda untuk membedakan ISK dengan bakteriuria asimptomatik, tetapi leukosituria bukanlah petanda yang sensitif pada bayi. Crain dan Gershel pada penelitian prospektif melaporkan 33 bayi dari 430 bayi dengan demam kurang dari 8 minggu yang disebabkan oleh ISK. Dari 33 bayi tersebut hanya $48 \%$ di antaranya dengan leukosit atau terlihat bakteri pada pemeriksaan mikroskopis. ${ }^{13}$ Pada penelitian ini, KIH dengan biakan urin positif hanya 1 dari 24 pasien dengan leukosituria.

Pada penelitian ini demam hanya ditemukan pada 1 dari 24 pasien. Hal ini kemungkinan karena ISK bawah. Pada ISK bawah, walaupun tidak ada penyebaran bakteri ke aliran darah sistemik, masih mungkin menimbulkan kolestasis intrahepatik. Infeksi maupun non-infeksi yang menyebabkan aktivasi sitokin proinflamasi dapat menyebabkan peradangan/ inflamasi yang dapat menyebabkan kolestasis hepatoselular. Inflamasi yang menyebabkan kolestasis tidak bergantung pada penyebabnya, dimediasi oleh efek endotoksin misalnya lipopolisakarida (LPS) pada membran luar bakteri Gram negatif dan atau LPS yang merangsang sitokin proinflamasi seperti TNF-alpha dan berbagai interleukin. Telah diketahui bahwa sitokin proinflamasi adalah inhibitor yang poten untuk ekspresi gen transporter hepatobilier yang menyebabkan gangguan fungsi transport empedu dan menyebabkan terjadinya hiperbilirubinemia (kolestasis). ${ }^{14}$ Pada keadaan infeksi baik yang masuk ke dalam hati maupun di luar hati, bakteri dapat menghasilkan endotoksin dan endotoksin ini dapat masuk dalam sirkulasi walaupun bakteri yang menginfeksi tidak masuk dalam peredaran darah. ${ }^{11,15,16}$ Oleh sebab itu mungkin saja ditemukan kolestasis walaupun tidak ada bakteriemia. Endotoksin dapat merangsang sintesis sitokin oleh makrofag (di hati misalnya sel Kuppfer). Sel Kupffer dan sel imunokompeten lainnya dalam hati mensintesis sitokin intrahepatik seperti TNF-alpha, IL-1, IL-6, dan IL-8, sehingga sitokin intrahepatik meningkat jumlahnya, mengganggu fungsi hepatosit dan menyebabkan kolestasis. Selain itu sitokin juga dilepaskan oleh sel epitel duktus biliaris (kolangiosit) yaitu TNF-alpha dan IL-6. Hepatosit dan kolangiosit ternyata berkontribusi aktif pada respons sitokin proinflamasi. ${ }^{14,16}$ 
Pada penelitian ini penyebab ISK yang tersering adalah Eschericia coli dengan median gejala pertama pada usia 7 hari. Kolestasis pada neonatus relatif sering dijumpai (kurang lebih 1/3 dari seluruh kasus ikterus neonatal). Pada kelompok usia ini infeksi saluran kemih oleh E.coli merupakan penyebab yang paling sering. ${ }^{17} \mathrm{Ng}$ dan Rawstron melaporkan $E$. coli sebagai penyebab terbanyak, 3 dari 6 pasien ISK dengan gejala kolestasis adalah karena E.coli. ${ }^{4}$ Garcia dkk melaporkan E. coli juga merupakan penyebab ISK terbanyak (4/ 12 pasien). ${ }^{8}$

Terdapat pertanyaan yang menarik untuk diketahui: apakah pada penelitian ini pasien-pasien dengan biakan positif merupakan bakteriuria asimptomatik saja dan bukan ISK? Bila demikian maka tentunya bakteriuria tersebut tidak menyebabkan KIH. Bakteriuria asimptomatik umumnya ditemukan pada wanita muda, tetapi tidak biasa pada lelaki muda. Abbot dkk, ${ }^{18}$ dan Edelman dkk, ${ }^{19}$ melaporkan bakteria asimptomatik pada neonatus berkisar hanya $0,5-1 \%$. Mengingat pada penelitian ini dan penelitian lainnya ditemukan predominasi lelaki dan terjadi pada pasien yang sangat muda, maka ISK lebih mungkin terjadi daripada bakteriuria asimptomatik.

Kolestasis intra hepater dengan ISK tidak memiliki gejala yang khas. Hal ini sesuai dengan laporan penelitian sebelumnya yang berkesimpulan bahwa umumnya ikterus merupakan satu-satunya gejala infeksi pada pasien neonatus dan sering kali hubungan ikterus dengan infeksi mudah terlewatkan bila tidak disadari. ${ }^{11}$ Pada penelitian ini 11 dari 24 bayi dengan kolestasis intrahepatik membaik setelah diobati dengan antibiotik dan terapi standar kolestasis (ursodeoksikolat dan vitamin A,D, E, dan K). Telah diketahui bahwa walaupun terapi antibiotik berhasil mengeradikasi bakteri, resolusi ikterus dapat terlambat karena terbentuknya konjugasi protein bilirubin di dalam serum. ${ }^{4}$

Pada penelitian retrospektif memiliki beberapa kekurangan. Pemeriksaan biakan urin dengan kantung urin steril mempunyai bias biakan urin positif karena kontaminasi pada subyek masih mungkin terjadi. Oleh sebab itu, perlu dilakukan penelitian prospektif dengan mengambil sampel urin dengan cara pungsi suprapubis atau dengan kateterisasi saluran kemih. Pemeriksaan biakan darah sebaiknya juga dilakukan bersamaan untuk melihat apakah infeksi yang terjadi adalah infeksi ekstrahepatik atau intrahepatik. Bila memung- kinkan pemeriksaan kadar sitokin darah perlu dilakukan untuk memastikan bahwa walaupun infeksi terjadi ekstrahepatik memang terjadi pengeluaran sitokin sesuai dengan patogenesis kolestasis yang telah dikenal. Kelemahan lain penelitian ini adalah tidak dapat diambil kesimpulan yang pasti bahwa ISK merupakan satu-satunya penyebab $\mathrm{KIH}$ pada pasienpasien ini mengingat belum semua etiologi KIH dapat disingkirkan.

Kesimpulan: prevalens ISK pada bayi dengan $\mathrm{KIH}$ pada penelitian ini cukup tinggi (24/34) dengan dominasi lelaki (3:1) dan dengan bakteri penyebab tersering adalah bakteri Gram negatif (21/24), 15 dari 24 orang di antaranya adalah karena E. coli. Tidak ada gejala klinis yang spesifik pada kolestasis dengan ISK. Demam pada umumnya tidak ditemukan. Pemeriksaan urinalisis tidak sensitif untuk mendiagnosis $\mathrm{KIH}$ dengan ISK. Oleh sebab itu dianjurkan melakukan pemeriksaan biakan urin untuk mendeteksi ISK.

\section{Daftar Pustaka}

1. Suchy FJ. Approach to the infant with cholestasis. Dalam: Suchy FJ, Sokol RJ, Balistreri WF, penyunting. Liver disease in children. Edisi kedua. Philadelphia: Lippincott William \& Wilkins; 2001. h. 187-94.

2. Trauner M, Fickert P, Stauber RE. Inflammation-induced cholestasis. J. Gastroenterol hepatol 1999; 14:846-59.

3. Seeler RA, Hahn K. Jaundice in urinary tract infection in infancy. Am J Dis Child 1969; 118:553-9.

4. Ng SH, Rawstron JR. Urinary tract infections presenting with jaundice. Arch Dis Child 1971; 46:173-6.

5. Rosenthal P. Neonatal hepatitis and congenital infections. Dalam: Suchy FJ, Sokol RJ, Balistreri WF, penyunting. Liver disease in children. Edisi kedua. Philadelphia: Lippincott William \& Wilkins; 2001. h. 23952.

6. Chavalitdhamrong P, Escobedo MB, Barton LL, Zarkowsky H, Marshall RE. Hyperbilirubinemia and bacterial infection in the newborn. Arch Dis Child 1975; 50:652-4.

7. Rooney J, Hill DJ, Danks DM. Jaundice associated with bacterial infection in the newborn. Am J Dis Child 1971; 122:39-41.

8. Garcia FJ, Nager AL. Jaundice as an early diagnostic sign of urinary tract infection in infancy. Pediatrics 2002; 109:846-51. 
9. American Academy of Pediatrics, Provisional Committee for Quality improvement and Subcomittee on Hyperbilirubinemia. Practice parameter: management of hyperbilirubinemia in the healthy term newborn. Pediatrics 1994; 94:558-65.

10. Heldrich FJ, Barone MA, Spiegler E. UTI:diagnosis and evaluation in symptomatic pediatric patient. Clin Pediatr 2000; 39:461-71.

11. Zimmerman HJ, Fang M, Utili R, Seeff LB, Hoofnagle J. Jaundice due to bacterial infection. Gastroenterology 1979; 77:362-74.

12. Miller DJ, Keeton GR, Webber BL, Saunders SJ. Jaundice in severe bacterial infection. Gastroenterology 1976; 71: 94-7.

13. Crain EF, Gershel JC. Urinary tract infections in febrile infants younger than 8 weeks of age. Pediatrics 1990; 86:363-7.
14. Crawford JM, Boyer JL. Clinicopathology conferences: Inflammation-induced cholestasis. Hepatology 1998; 28: 253-60.

15. Simpson KJ, Lukacs NW, Colletti L, Strieter RM, Kunkel SL. Cytokines and the liver. J. Hepatol. 1997; 27: $1120-32$

16. Crawford JM. Cellular and molecular biology of the inflamed liver. Curr. Opin. Gastroenterol. 1997; 13:17585.

17. Escobedo MB, Barton LL, Marshall RE, Zarkowsky H. The frequency of jaundice in neonatal bacterial infections. Clin. Pediatr. 1974; 13:656-7.

18. Abbot GD. Neonatal bacteriuria: a prospective study of 1460 infants. Br Med J 1972; 1:267-9.

19. Edelman CM, Ogwo JE, Fine BP, Martinez AB. The prevalence of bacteriuria in full-term and premature newborn infants. J Pediar 1973; 82:125-32. 